\title{
The Effect of Eclipta Alba Leaves Extract on the Corrosion Inhibition Process of Carbon Steel in Sea Water
}

\author{
V. Johnsirani, ${ }^{a,{ }^{*}}$ J. Sathiyabama, ${ }^{a}$ S. Rajendran, ${ }^{a, b}$ \\ S.M. Lydia Christy ${ }^{c}$ and J. Jeyasundari ${ }^{d}$ \\ ${ }^{a} P G$ and Research Department of Chemistry, GTN Arts college, Dindigul - 624005, Tamil Nadu, India \\ ${ }^{b}$ Department of Chemistry, RVS School of Engineenring and Technology, Dindigul-624005, India \\ ${ }^{c}$ Department of Chemistry, VSB Engineering College, Karur - 639111, Tamil Nadu, India \\ ${ }^{d}$ Department of Chemistry, SVN College, Madurai, Tamil Nadu, India
}

Received 23 November 2012; accepted 17 April 2013

\begin{abstract}
The inhibition efficiency [IE] of an aqueous extract of eclipta alba leaves in controlling corrosion of carbon steel in sea water [Thondi, Tamil Nadu, India] has been evaluated by weight loss method. The weight loss study reveals that the formulation consisting of $6 \mathrm{~mL}$ of EAE (Eclipta Alba extract ) and $25 \mathrm{ppm}$ of $\mathrm{Zn}^{2+}$ has $92 \%$ inhibition efficiency in controlling corrosion of carbon steel in sea water. Polarization study reveals that EAE and $\mathrm{Zn}^{2+}$ system functions as a mixed type inhibitor. AC impedance spectra reveal that a protective film is formed on the metal surface. The nature of the metal surface has been analysed by FTIR spectra and AFM analysis.
\end{abstract}

Keywords: corrosion inhibition, Eclipta Alba, carbon steel, sea water, AFM,FTIR, green inhibitor.

\section{Introduction}

The major chemical constituents of seawater are consistent worldwide. However, seawater is still a complex chemical system affected by various other factors. These include the concentration and access of dissolved oxygen, salinity, concentration of minor ions, biological activity and pollutants [1-2]. Several inhibitors have been used to control corrosion of metals in sea water.

Most of the inhibitors are synthetic chemicals which may be very expensive and hazardous to living creatures and environment. Natural products are one of the renewable sources, which can be used as inhibitors. Natural products in addition to their environmental friendly and ecologically acceptable nature are

\footnotetext{
*Corresponding author. E-mail address: johnsirani15@gmail.com
} 
inexpensive, readily available and renewable sources of materials [3]. Among these so - called "green corrosion inhibitors" are organic compounds that act by adsorption on the metallic surfaces [4]. Some of these materials are honey [5], caffeic acid [6], caffeine [7], pennyroyal oil [8], alizarin [9], occimumviridis extract [10], rhizome extract [11], Zenthoxylum alatum extract [12], Lowsonia [13-14], Berberine [15], garlic extract [16] and extracts of several natural substances [17 -18].

In the present research work the extract of Eclipta alba leaves is taken as it is a good corrosion inhibitor for carbon steel in marine media collected from Bay of Bengal at Thondi, a small town located in Ramnad District, Tamil Nadu, India. Eclipta alba, a medicinal herb, is grown in many parts of India. The parts of the whole plant are used to cure many diseases. In ayirvedic medicine, the leaf extract is considered a powerful liver tonic, rejuvenative, and especially good eclipta prostrate is used for dyeing hair and tattooing [19-20].

Figure 1. Leaves of Eclipta Alba.

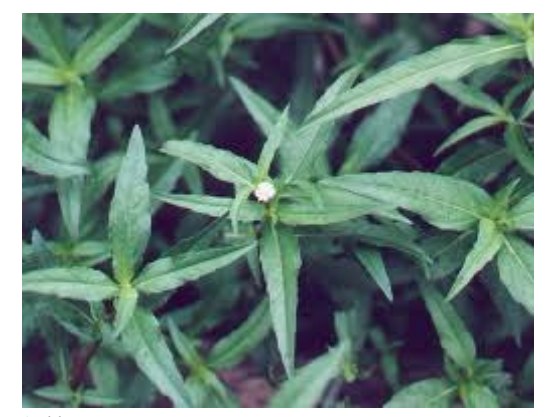

The present work is undertaken:

1. To evaluate the inhibition efficiency (IE) of Eclipta alba extract (EAE)- $\mathrm{Zn}^{2+}$ system in controlling corrosion of carbon steel immersed in sea water in the absence and presence of $\mathrm{Zn}^{2+}$ by weight loss method.

2. To study the mechanism of corrosion inhibition by polarization study and AC impedance spectra.

3. To analyse the protective film by FTIR spectra and Atomic Force Microscope (AFM).

4. To propose the mechanism of corrosion inhibition based on the above results.

\section{Materials and methods}

\section{Preparation of the plant extract}

The leaves of Eclipta Alba were dried and ground to powder and $10 \mathrm{~g}$ of the powdered leaves were weighed and boiled with double distilled water. The extract was filtered to remove suspending impurities, and made up to $100 \mathrm{~mL}$. The extract was used as corrosion inhibitor in the present study.

\section{Preparation of the specimen}

Carbon steel specimens $(0.026 \% \mathrm{~S}, 0.06 \% \mathrm{P}, 0.4 \% \mathrm{Mn}, 0.1 \% \mathrm{C}$ and rest iron) of the dimensions $1.0 \times 4.0 \times 0.2 \mathrm{~cm}$ were polished to a mirror finish, degreased 
with trichloroethylene, and used for the weight-loss method and surface examination studies.

\section{Weight-loss method}

Carbon steel specimens were immersed in $100 \mathrm{~mL}$ of the medium containing various concentrations of the inhibitor in the absence and presence of $\mathrm{Zn}^{2+}$ for 1 day. The weights of the specimens before and after immersion were determined using a balance Shimadzu AY62 model. The corrosion IE was then calculated using the equation

$$
\mathrm{IE}=100\left[1-\left(\mathrm{W}_{2} / \mathrm{W}_{1}\right)\right] \%
$$

where $\mathrm{W}_{1}$ is the weight loss value in the absence of inhibitor and $\mathrm{W}_{2}$ is the weight loss value in the presence of inhibitor.

The corrosion rate was calculated using the formula [21]

$$
\text { Corrosion rate }(\mathrm{mm} / \text { year })=87.6 \mathrm{~W} / \mathrm{DAT}
$$

where $\mathrm{W}=$ weight loss in milligrams, $\mathrm{D}=$ density of the specimen $\mathrm{g} / \mathrm{cm}^{3}, \mathrm{~A}=$ area of specimen in square $\mathrm{cm}, \mathrm{T}=$ exposure time in hours.

\section{Potentiodynamic polarization study}

Polarization studies were carried out in a CHI- electrochemical work station with impedance model 660A. It was provided with iR compensation facility. A three electrode cell assembly was used. The working electrode was carbon steel. A saturated calomel electrode (SCE) was the reference electrode. Platinum was the counter electrode. From polarization study, corrosion parameters such as corrosion potential $\left(\mathrm{E}_{\mathrm{corr}}\right)$, corrosion current $\left(\mathrm{I}_{\mathrm{corr}}\right)$, Tafel slopes anodic $=\mathrm{b}_{\mathrm{a}}$ and cathodic $=b_{c}$ were calculated, and linear polarization study (LPR) was done. The scan rate $(\mathrm{V} / \mathrm{S})$ was 0.01 . Hold time at $\left(\mathrm{E}_{\mathrm{fcs}}\right)$ was zero and quiet time $(\mathrm{s})$ was two.

\section{AC impedance spectra}

The instrument used for polarization study was used to record AC impedance spectra also. The cell set up was also the same. The real part (Z') and imaginary part $(Z$ ') of the cell impedance were measured in ohms at various frequencies. Values of charge transfer resistance $\left(R_{t}\right)$ and the double layer capacitance $\left(C_{d l}\right)$ were calculated.

\section{Surface examination study}

The carbon steel specimens were immersed in various test solutions for a period of one day. After one day, the specimens were taken out and dried. The nature of the film formed on the surface of the metal specimen was analyzed for surface analysis technique by FTIR spectra and Atomic Force Microscopy.

\section{Fourier transform infrared spectra}

These spectra were recorded in a Perkin-Elmer-1600 spectrophotometer using $\mathrm{KBr}$ pellet. The FTIR spectrum of the protective film was recorded by carefully removing the film, mixing it with $\mathrm{KBr}$ and making the pellet. 


\section{Atomic Force Microscopy characterization (AFM)}

The carbon steel specimens immersed in blank and in the inhibitor solution for a period of one day were removed, rinsed with double distilled water, dried and subjected to the surface examination. Atomic force microscopy (Veeco dinnova model) was used to observe the samples' surface in tapping mode, using cantilever with linear tips. The scanning area in the images was $5 \mu \mathrm{m} \times 5 \mu \mathrm{m}$ and the scan rate was $0.6 \mathrm{HZ} / \mathrm{second}$.

\section{Results and discussion}

The physicochemical parameters of sea water used in the present study are given in Table 1.

Table 1. Water analysis (Thondi sea water, Tamil Nadu, India).

\begin{tabular}{|c|c|}
\hline Parameters & Result \\
\hline Total dissolved salts (mg/L) & $30539 \mathrm{ppm}$ \\
\hline Electrical conductivity (micro mhos/cm) & 44910 \\
\hline $\mathrm{pH}$ & 7.06 \\
\hline Total hardness $\left(\mathrm{CaCO}_{3}\right.$ equivalent $)$ & $100 \mathrm{ppm}$ \\
\hline Calcium as $\mathrm{Ca}(\mathrm{mg} / \mathrm{L})$ & $19 \mathrm{ppm}$ \\
\hline Magnesium as $\mathrm{Mg}(\mathrm{mg} / \mathrm{L})$ & $12 \mathrm{ppm}$ \\
\hline Sodium as $\mathrm{Na}(\mathrm{mg} / \mathrm{L})$ & 0 \\
\hline Chloride as $\mathrm{Cl}(\mathrm{mg} / \mathrm{L})$ & $11400 \mathrm{ppm}$ \\
\hline Fluoride as F (mg/L) & 0 \\
\hline Free ammonia as $\mathrm{NH}_{3}(\mathrm{mg} / \mathrm{L})$ & 0 \\
\hline Sulphate as $\mathrm{SO}_{4}(\mathrm{mg} / \mathrm{L})$ & 6708 ppm \\
\hline
\end{tabular}

Table 2. The corrosion inhibition efficiencies and the corresponding corrosion rates (millimeter per year) of EAE $-\mathrm{Zn}^{2+}$ system.

\begin{tabular}{|c|c|c|c|c|c|c|}
\hline \multirow{3}{*}{$\begin{array}{l}\text { Inhibitor } \\
\text { EAE (mL) }\end{array}$} & \multicolumn{6}{|c|}{$\mathrm{Zn}^{2+}(\mathbf{p p m})$} \\
\hline & \multicolumn{2}{|c|}{ 0 } & \multicolumn{2}{|r|}{25} & \multicolumn{2}{|r|}{50} \\
\hline & IE\% & $\mathrm{CR}(\mathrm{mm} / \mathrm{y})$ & IE\% & $\mathrm{CR}(\mathrm{mm} / \mathrm{y})$ & IE\% & $\mathrm{CR}(\mathrm{mm} / \mathrm{y})$ \\
\hline 0 & - & 0.1576 & 16 & 0.1323 & 47 & 0.0835 \\
\hline 2 & 50 & 0.0788 & 65 & 0.0555 & 70 & 0.0472 \\
\hline 4 & 55 & 0.0354 & 71 & 0.0457 & 76 & 0.0378 \\
\hline 6 & 60 & 0.0630 & 92 & 0.0126 & 80 & 0.0315 \\
\hline 8 & 63 & 0.0583 & 88 & 0.0189 & 82 & 0.0283 \\
\hline 10 & 65 & 0.0555 & 80 & 0.0315 & 85 & 0.0236 \\
\hline
\end{tabular}


The calculated inhibition efficiencies (IE) of Eclipta alba Extract in controlling the corrosion of carbon steel immersed in sea water both in the absence and presence of zinc ion have been tabulated in Table 2. The calculated values indicate the ability of Eclipta alba extract to be a good corrosion inhibitor. The inhibition efficiency is found to be enhanced in the presence of zinc ion. The formulation consisting of $6 \mathrm{~mL}$ of EAE and $25 \mathrm{ppm}$ of $\mathrm{Zn}^{2+}$ offers $92 \%$ inhibition efficiency. That is, the mixture of the inhibitors shows better IE than the individual inhibitors [22].

\section{Synergism parameter $\left(S_{I}\right)$}

Synergism parameters are indications of the synergistic effect existing between inhibitors [23-26]. $S_{I}$ value is found to be greater than one, indicating the synergistic effect existing between $\mathrm{Zn}^{2+}$ of concentrations $25 \mathrm{ppm}$ and $50 \mathrm{ppm}$ with various concentrations of EAE. The results are given in Table 3.

Synergism parameters were calculated using the relation

$$
\mathrm{S}_{\mathrm{I}}=1-\theta_{1+2} / 1-\theta^{\prime}{ }_{1+2}
$$

where $\theta_{1+2}=\left(\theta_{1}+\theta_{2}\right)-\left(\theta_{1} \times \theta_{2}\right) ; \theta_{1}=$ surface coverage of inhibitor (EAE); $\theta_{2}=$ surface coverage of inhibitor $\left(\mathrm{Zn}^{2+}\right) ; \theta^{\prime}{ }_{1+2}=$ combined surface coverage of inhibitors $(\mathrm{EAE})$ and $\left(\mathrm{Zn}^{2+}\right)$ surface coverage $=\mathrm{IE} \% / 100$.

Table 3. Synergism parameter $\left(\mathrm{S}_{\mathrm{I}}\right)$.

\begin{tabular}{|c|c|c|c|c|c|c|c|}
\hline $\begin{array}{l}\text { EAE } \\
(\mathbf{m L})\end{array}$ & $\theta_{1}$ & $\begin{array}{c}\mathrm{Zn}^{2+} \\
25(\mathrm{ppm}) \\
\theta_{2}\end{array}$ & $\begin{array}{c}\text { EAE- } \mathbf{Z n}^{2+} \\
\theta_{1+2}^{\prime}\end{array}$ & $\mathbf{S}_{\mathbf{I}}$ & $\begin{array}{l}\mathrm{Zn}^{2+} \\
50(\mathrm{ppm}) \\
\theta_{2}\end{array}$ & $\begin{array}{c}\text { EAE- } \mathbf{Z n}^{2+} \\
\theta_{1+2}^{\prime}\end{array}$ & $\mathbf{S}_{\mathbf{I}}$ \\
\hline 2 & 0.50 & 0.16 & 0.65 & 1.2 & 0.47 & 0.70 & 0.883 \\
\hline 4 & 0.55 & 0.16 & 0.71 & 1.3034 & 0.47 & 0.76 & 0.9937 \\
\hline 6 & 0.60 & 0.16 & 0.92 & 4.2 & 0.47 & 0.80 & 1.21 \\
\hline 8 & 0.63 & 0.16 & 0.88 & 2.49 & 0.47 & 0.82 & 1.0894 \\
\hline 10 & 0.65 & 0.16 & 0.80 & 1.47 & 0.47 & 0.85 & 1.2366 \\
\hline
\end{tabular}

\section{Potentiodynamic polarization study}

Polarization study has been used to detect the formation of a protective film on the metal surface [27-32]. When a protective film is formed on the metal surface, the linear polarization resistance (LPR) increases and the corrosion current $\left(\mathrm{I}_{\text {corr }}\right)$ decreases. The potentiodynamic polarization curves of carbon steel immersed in various test solutions are shown in Fig. 2. The corrosion parameters namely, corrosion potential ( $\left.\mathrm{E}_{\mathrm{corr}}\right)$, Tafel slopes $\left(\mathrm{b}_{\mathrm{c}}=\right.$ cathodic; $\mathrm{b}_{\mathrm{a}}=$ anodic $)$, linear polarization resistance (LPR) and corrosion current $\left(\mathrm{I}_{\text {corr }}\right)$ are given in Table 4.

When carbon steel is immersed in sea water, the corrosion potential is $-816 \mathrm{mV}$ vs. SCE. The formulation consisting of $6 \mathrm{~mL}$ of EAE solution and $25 \mathrm{ppm}$ of $\mathrm{Zn}^{2+}$ shifts the corrosion potential to $-820 \mathrm{mV}$ vs. SCE. The corrosion potential shift is very small. This suggests that the EAE- $\mathrm{Zn}^{2+}$ formulation functions as a 
mixed inhibitor controlling the anodic reaction and cathodic reaction to the same extent.

The corrosion current value and LPR value for sea water are $6.354 \times 10^{-6} \mathrm{~A} / \mathrm{cm}^{2}$ and $6.500 \times 10^{3} \mathrm{Ohm} \mathrm{cm}$. For the formulation of EAE $(6 \mathrm{~mL})$ and $\mathrm{Zn}^{2+}(25$ $\mathrm{ppm})$, the corrosion current value has decreased to $5.863 \times 10^{-6} \mathrm{~A} / \mathrm{cm}^{2}$, and the LPR value has increased to $6.909 \times 10^{3} \mathrm{Ohm} \mathrm{cm}^{2}$. This indicates that a protective film is formed on the metal surface. When a protective film is formed on the metal surface LPR value increases and corrosion current value decreases.

Table 4. Potentiodynamic polarization curves of carbon steel immersed in various test solution

\begin{tabular}{|c|c|c|c|c|c|}
\hline System & $\begin{array}{c}E_{\text {corr }} \\
\text { mV vs. SCE }\end{array}$ & $\begin{array}{c}\mathbf{b}_{\mathbf{c}} \\
\mathrm{mV} / \mathrm{dec} \text { ede }\end{array}$ & $\begin{array}{c}\mathbf{b}_{\mathbf{a}} \\
\mathrm{mV} / \mathrm{decade}\end{array}$ & $\begin{array}{c}\text { LPR } \\
\text { Ohm } \text { cm }^{2} \\
\end{array}$ & $\begin{array}{c}\mathbf{I}_{\text {corr }} \\
\mathbf{A} / \mathbf{c m}^{2}\end{array}$ \\
\hline Sea water & -816 & 157 & 239 & $6.500 \times 10^{3}$ & $6.354 \times 10^{-6}$ \\
\hline $\begin{array}{l}\text { Sea water }+6 \mathrm{~mL} \\
\mathrm{EAE}+25 \mathrm{ppm} \mathrm{Zn}^{2+}\end{array}$ & -820 & 151 & 240 & $6.909 \times 10^{3}$ & $5.863 \times 10^{-6}$ \\
\hline
\end{tabular}

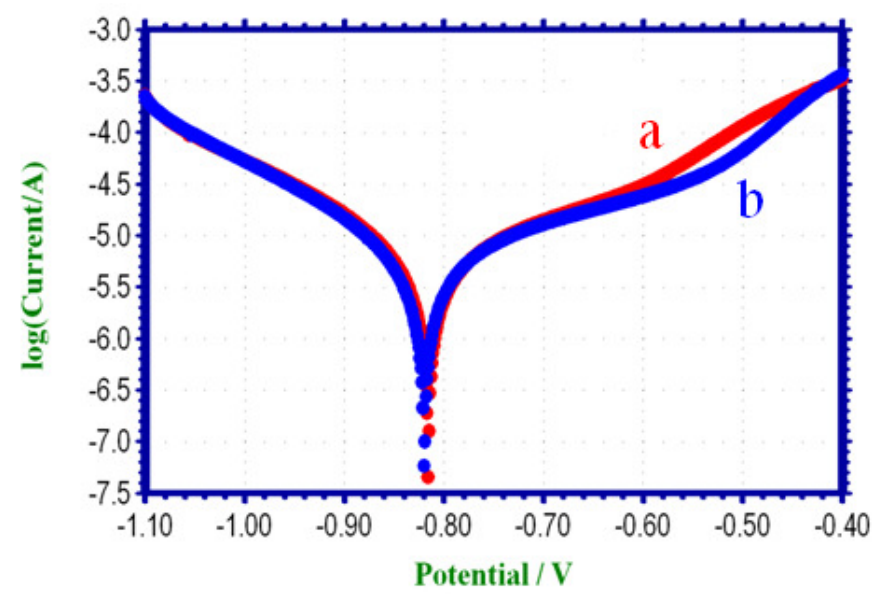

Figure 2. Polarization curves of carbon steel immersed in various test solutions; (a) sea water; (b) sea water $+\mathrm{EAE} 6 \mathrm{~mL}+\mathrm{Zn}^{2+} 25 \mathrm{ppm}$.

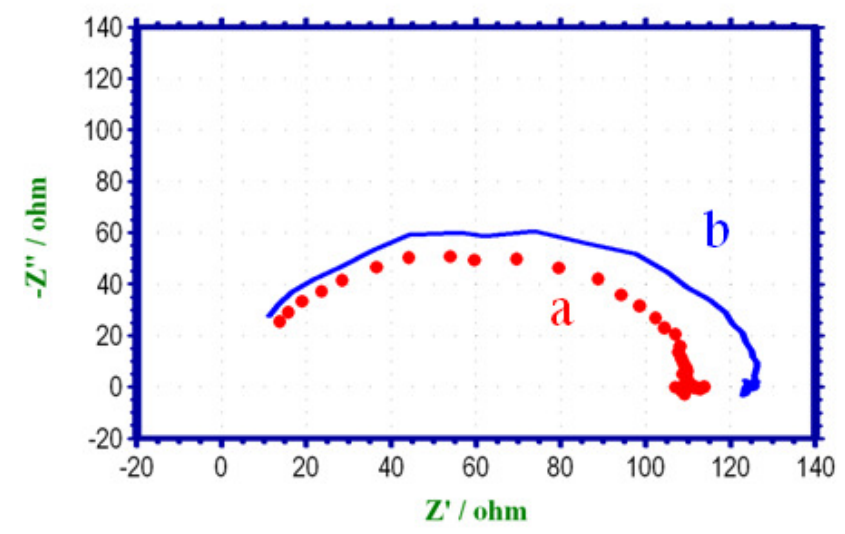

Figure 3. AC impedance spectra of carbon steel immersed in various test solutions; a) sea water; b) sea water + EAE $6 \mathrm{~mL}+\mathrm{Zn}^{2+} 25 \mathrm{ppm}$. 


\section{Analysis of AC impedance spectra}

AC impedance spectra have been studied to detect the formation of a film on the metal surface. If a protective film is formed, the charge transfer resistance increases and the double layer capacitance value decreases [33-37]. The AC impedance spectra of carbon steel immersed in various solutions are shown in Fig. 3. The AC impedance parameter, namely charge transfer resistance $\left(R_{t}\right)$ and double layer capacitance $\left(\mathrm{C}_{\mathrm{dl}}\right)$ (derived from Nyquist plot) are given in Table 5.

Table 5. AC impedance parameters of carbon steel immersed in various test solutions.

\begin{tabular}{|c|c|c|c|}
\hline System & $R_{t}\left(O h m c^{2}\right)$ & $\mathrm{C}_{\mathrm{dl}}\left(\mathrm{F} / \mathrm{cm}^{2}\right)$ & $\begin{array}{c}\text { Impedance value } \\
\log (\mathrm{z} / \mathrm{Ohm})\end{array}$ \\
\hline Sea water & 101.10 & $5.0445 \times 10^{-8}$ & 2.060 \\
\hline EAE $6 \mathrm{~mL}+\mathrm{Zn}^{2+} 25 \mathrm{ppm}$ & 111.43 & $4.576 \times 10^{-8}$ & 2.101 \\
\hline
\end{tabular}

\section{Analysis of FTIR spectra}

The active principle in an aqueous extract of Eclipta Alba extract is wedelolactone. The green colour of the extract is due to wedelolactone. The main constituent of Eclipta Alba is wedelolactone. The structure of wedelolactone is shown in Scheme 1. It contains 1,8,9-trihydroxy-3-methoxy- $6 \mathrm{H}$-[1] benzofuro [3,2-c] chromen-6- one [38-39].

The wedelolactone extract was evaporated to dryness to get a solid mass. Its FTIR spectrum is shown in Fig. 4a. The $-\mathrm{OH}$ stretching frequency appears at $3413 \mathrm{~cm}^{-1}$. The $\mathrm{C}=\mathrm{O}$ stretching frequency appears at $1634 \mathrm{~cm}^{-1}$. The FTIR spectrum of the protective film formed on the surface of the metal after immersed in the solution containing $25 \mathrm{ppm}$ of $\mathrm{Zn}^{2+}$ and $6 \mathrm{~mL}$ of EAE is shown in Fig. 4b. It is found that the $-\mathrm{OH}$ has shifted from $3413 \mathrm{~cm}^{-1}$ to $3375 \mathrm{~cm}^{-1}$. The $\mathrm{C}=\mathrm{O}$ stretching frequency has decreased from $1634 \mathrm{~cm}^{-1}$ to $1596 \mathrm{~cm}^{-1}$. The ring oxygen appeared at $1090 \mathrm{~cm}^{-1}$. It has coordinated $\mathrm{Fe}^{2+}$ to form a protective film on the metal surface. The peak at $1365 \mathrm{~cm}^{-1}$ is due to $\mathrm{Zn}-\mathrm{O}$ stretching. Peak at $3375 \mathrm{~cm}^{-1}$ is due to $-\mathrm{OH}$ stretching. So, it is concluded that $\mathrm{Zn}(\mathrm{OH})_{2}$ is formed on cathodic sites of the metal surface [40].

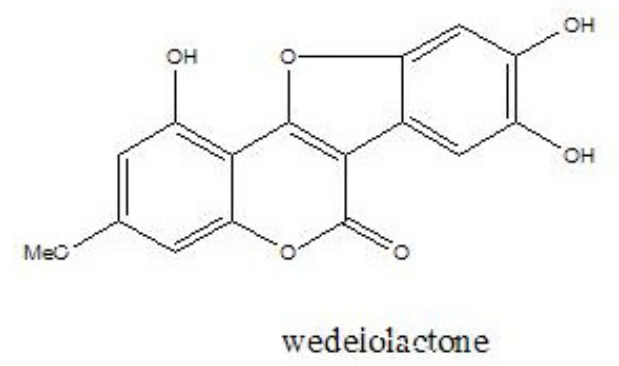

Scheme 1. Structure of wedelolactone (extract of eclipta alba): 1,8,9-trihydroxy-3methoxy- $6 \mathrm{H}-[1]$ benzofuro [3,2-c] chromen-6-one. 

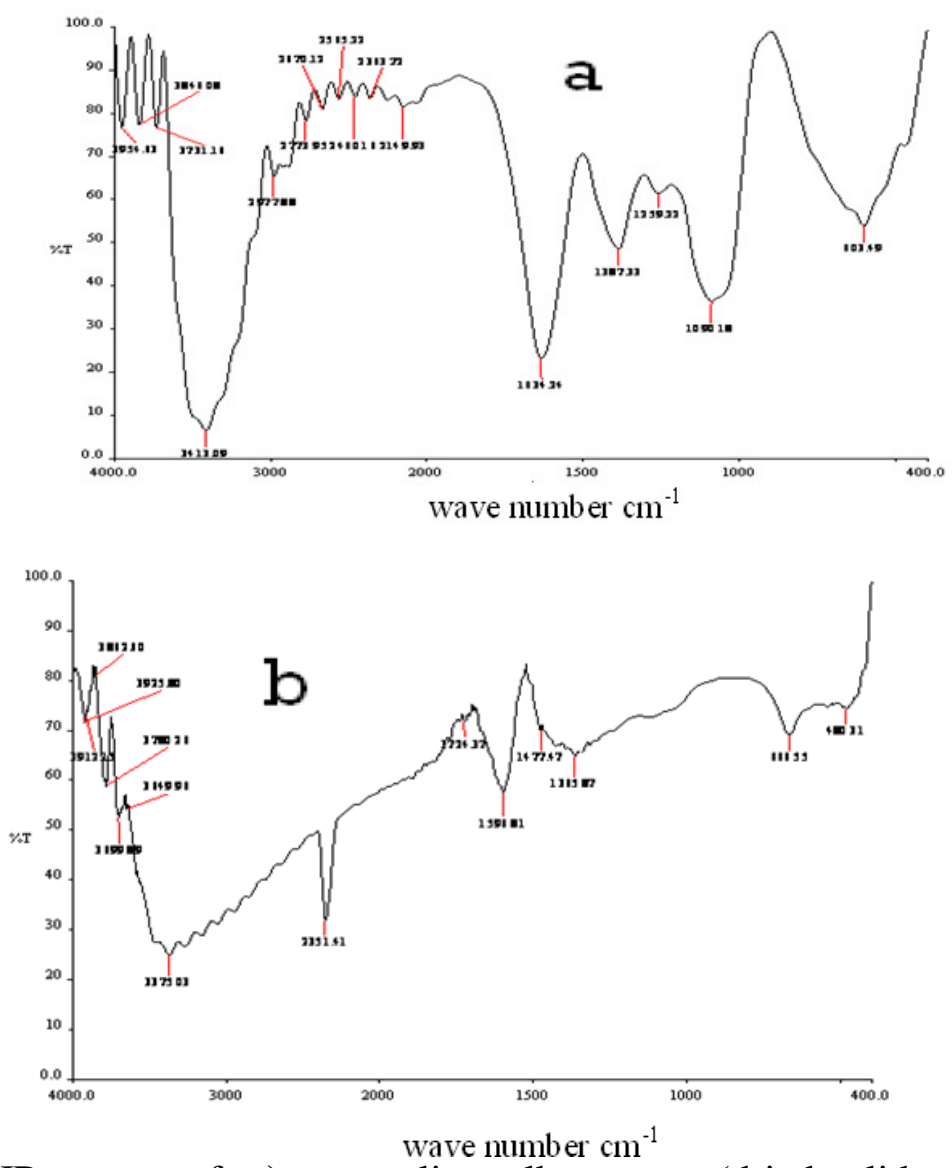

Figure 4. FTIR spectra of: a) pure eclipta alba extract (dried solid mass, KBr); and b) the film formed on the metal surface after immersion in sea water containing $6 \mathrm{~mL}$ of EAE- 25 ppm $\mathrm{Zn}^{2+}$.

\section{Atomic Force Microscopy characterization}

AFM is a powerful technique to investigate the surface morphology at nano -to micro - scale and has become a new choice to study the influence of the inhibitor on the generation and the progress of the corrosion at the metal/solution interface [41-43]. The three dimensional (3D) AFM morphologies and the AFM cross-sectional profile for polished carbon steel surface (reference sample), carbon steel surface immersed in sea water (blank sample) and carbon steel surface immersed in sea water containing the formulation of $8 \mathrm{~mL}$ of $\mathrm{HE}$ and $25 \mathrm{ppm}$ of $\mathrm{Zn}^{2+}$ are shown as Fig. 5 [images (a,d,g ), (b,e,h),(c,f,i), respectively].

\section{Root mean square roughness, average and roughness and peak-to-valley value}

AFM image analysis is performed to obtain the average roughness, $R_{a}$ (the average deviation of all points of the roughness profile from a mean line over the evaluation length), root-mean-square roughness, $\mathrm{R}_{\mathrm{q}}$ (the average of the measured height deviations taken within the evolution length and measured from the mean line) and the maximum peak-to-valley (p-v) height values (largest single peak-tovalley height in five adjoining sampling heights) [41]. Table 6 is a summary of $\left(\mathrm{R}_{\mathrm{q}}\right)$, $\left(\mathrm{R}_{\mathrm{a}}\right)$, (P-V) values for carbon steel surface immersed in different environments. 

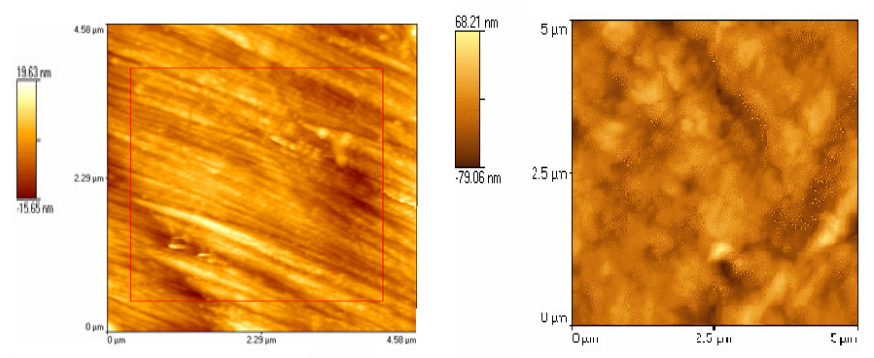

a

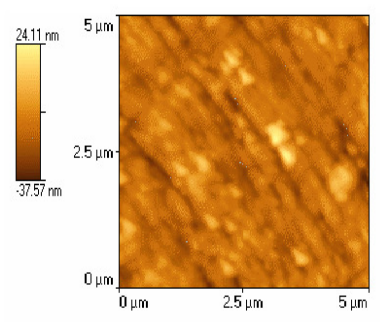

c

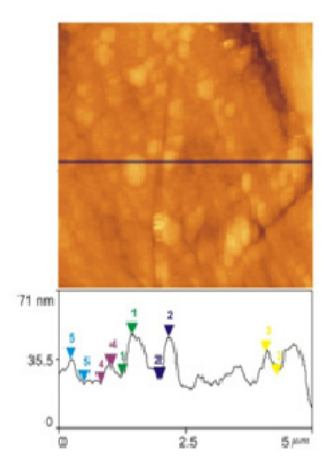

d
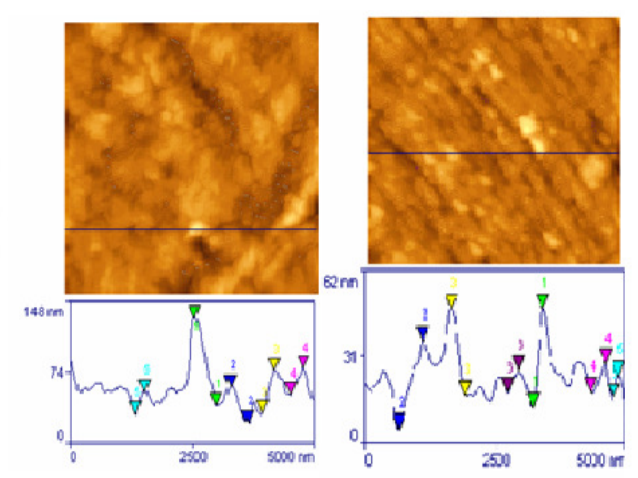

e $\mathrm{f}$

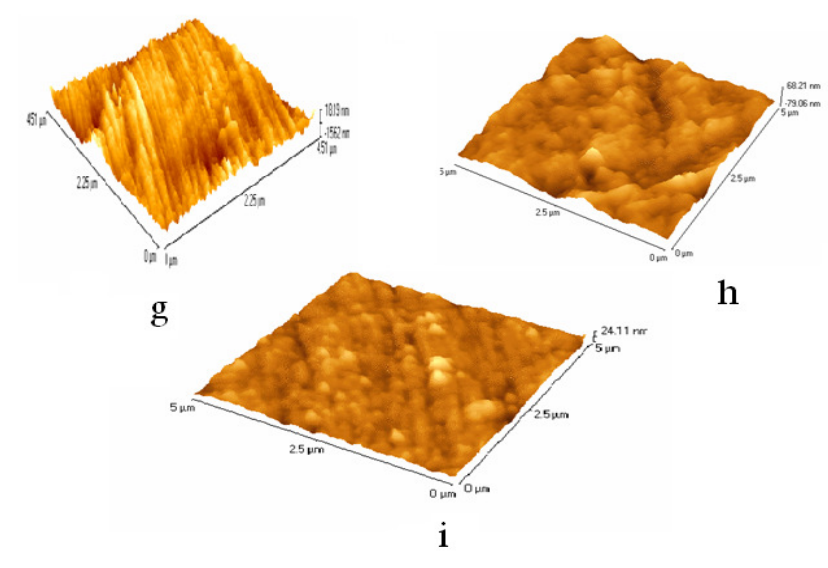

Figure 5. Two dimensional AFM images of the surface of: a) polished carbon steel (control); b) carbon steel immersed in sea water (blank); c) carbon steel immersed in sea water containing EAE $(6 \mathrm{~mL})+\mathrm{Zn}^{2+}(25 \mathrm{ppm})$; d) polished carbon steel (control); e) carbon steel immersed in sea water (blank); f) carbon steel immersed in sea water containing $\left.\mathrm{EAE}(6 \mathrm{~mL})+\mathrm{Zn}^{2+}(25 \mathrm{ppm}) ; \mathbf{g}\right)$ polished carbon steel (control); h) carbon steel immersed in sea water (blank); i) carbon steel immersed in sea water containing EAE (6 $\mathrm{mL})+\mathrm{Zn}^{2+}(25 \mathrm{ppm})$. 
Fig. 5 (a,d,g) displays the surface topography of un-corroded metal surface. The values of $\mathrm{R}_{\mathrm{q}}, \mathrm{Ra}$ and $\mathrm{p}-\mathrm{v}$ height for the polished carbon steel surface (reference sample) are $4.3 \mathrm{~nm}, 3.4 \mathrm{~nm}$ and $35.28 \mathrm{~nm}$, respectively. The slight roughness observed on the polished carbon steel surface is due to atmospheric corrosion.

Fig. 5 (b,e,h) displays the corroded metal surface with few pits in the absence of the inhibitor immersed in sea water. The $\left(R_{q}\right),\left(R_{a}\right),(p-v)$ height values for the carbon steel surface are $17.10 \mathrm{~nm}, 13.58 \mathrm{~nm}$ and $92.28 \mathrm{~nm}$, respectively. These data suggest that the carbon steel surface immersed in sea water has a greater surface roughness than the polished metal surface, which shows that the unprotected carbon steel surface is rougher due to the corrosion of the carbon steel in sea water environment.

Table 6. AFM data for carbon steel surface immersed in inhibited and uninhibited environments.

\begin{tabular}{|l|c|c|c|}
\hline Samples & $\begin{array}{c}\text { RMS }\left(\mathbf{R}_{\mathbf{q}}\right) \\
\text { Roughness }(\mathbf{n m})\end{array}$ & $\begin{array}{c}\text { Average }\left(\mathbf{R}_{\mathbf{a}}\right) \\
\text { Roughness }(\mathbf{n m})\end{array}$ & $\begin{array}{c}\text { Maximum Peak-to- } \\
\text { Valley height (nm) }\end{array}$ \\
\hline 1. Polished carbon steel (Control) & 4.33 & 3.41 & 35.28 \\
\hline $\begin{array}{l}\text { 2. Carbon steel immersed in sea water } \\
\text { (blank) }\end{array}$ & 17.10 & 13.58 & 92.28 \\
\hline $\begin{array}{l}\text { 3. Carbon steel immersed in sea water } \\
+ \text { EAE }(6 \mathrm{~mL})+\mathrm{Zn}^{2+} 25(\mathrm{ppm})\end{array}$ & 8.74 & 6.48 & 35.32 \\
\hline
\end{tabular}

Fig. 5 (c,f,i) displays the surface after immersion in sea water containing $6 \mathrm{~mL}$ of EAE and $25 \mathrm{ppm}$ of $\mathrm{Zn}^{2+}$. The $\left(\mathrm{R}_{\mathrm{q}}\right),\left(\mathrm{R}_{\mathrm{a}}\right)(\mathrm{p}-\mathrm{v})$ height values for the carbon steel surface are $8.74 \mathrm{~nm}, 6.48 \mathrm{~nm}$ and $35.32 \mathrm{~nm}$, respectively. The $\left(\mathrm{R}_{\mathrm{q}}\right),\left(\mathrm{R}_{\mathrm{a}}\right)(\mathrm{p}-\mathrm{v})$ height values are considerably less in the inhibited environment compared to the uninhibited environment. These parameters confirm that the surface is smoother. The smoothness of the surface is due to the formation of a compact protective film of $\mathrm{Fe}^{2+}$-EAE complex and $\mathrm{Zn}(\mathrm{OH})_{2}$ on the metal surface thereby inhibiting the corrosion of carbon steel [41].

\section{Mechanism of corrosion inhibition}

Weight loss method reveals that the formulation consisting of $6 \mathrm{~mL}$ of EAE and $25 \mathrm{ppm}$ of $\mathrm{Zn}^{2+}$ offers $92 \%$ IE to carbon steel immersed in sea water. Polarization study reveals that EAE- $\mathrm{Zn}^{2+}$ system functions as a mixed inhibitor. FTIR spectra reveal that the protective film consists of $\mathrm{Fe}^{2+}$-wedelolactone complex and $\mathrm{Zn}(\mathrm{OH})_{2}$.

In order to explain the above facts in a holistic way, the following mechanism of corrosion inhibition is proposed:

- when the formulation consisting of sea water, eclipta alba extract and $\mathrm{Zn}^{2+}$ is prepared, there is formation of $\mathrm{Zn}^{2+}$-wedelolactone complex in solution;

- when carbon steel is immersed in the solution, the $\mathrm{Zn}^{2+}$-wedelolactone complex diffuses from the bulk of the solution towards the metal surface;

- on the metal surface, $\mathrm{Zn}^{2+}$-wedelolactone complex is converted into $\mathrm{Fe}^{2+}$ wedelolactone complex. $\mathrm{Zn}^{2+}$ is released

$$
\mathrm{Zn}^{2+} \text {-wedelolactone }+\mathrm{Fe}^{2+} \rightarrow \mathrm{Fe}^{2+} \text { - wedelolactone }+\mathrm{Zn}^{2+} \text {; }
$$

- the released $\mathrm{Zn}^{2+}$ combines with $\mathrm{OH}^{-}$to form $\mathrm{Zn}(\mathrm{OH})_{2}$ on the cathodic sites

$$
\mathrm{Zn}^{2+}+2 \mathrm{OH}^{-} \rightarrow \mathrm{Zn}(\mathrm{OH})_{2} \downarrow
$$


- thus the protective film consists of $\mathrm{Fe}^{2+}$-wedelolactone complex and $\mathrm{Zn}(\mathrm{OH})_{2}$.

\section{Conclusions}

The present study leads to the following conclusions:

1. The formulation consisting of $6 \mathrm{~mL}$ EAE and $25 \mathrm{ppm} \mathrm{Zn}^{2+}$ has $92 \%$ inhibition efficiency to carbon steel immersed in sea water.

2. Polarization study reveals that $E A E-\mathrm{Zn}^{2+}$ system functions as a mixed inhibitor.

3. AC impedance spectra reveal that a protective film is formed on the metal surface.

4.FTIR spectra reveal that the protective film consists of $\mathrm{Fe}^{2+}-$ wedelolactone complex and $\mathrm{Zn}(\mathrm{OH})_{2}$.

\section{Acknowledgement}

The authors are thankful to their respective management and DRDO, India.

\section{References}

1. ASM Metals Handbook. Vol 13: Corrosion, $9^{\text {th }}$ ed. Materials Park, OH: ASM Intermational; 1987. P. 893.

2. Moller H, Boshoff ET, Froneman H. J South Afr Inst Mining Metallurgy. 2006;106:592.

3. Nasibi M, Zaarei D, Danaee I. Chem Eng Comm. 2012:1.

4. Ostovari A, Hoseinieh SM, Peikari M. et al. Corros Sci. 2009;51:1935.

5. El-Etre AY, Abdallah M. Corros Sci. 2000;42:731.

6. Souza FS, Spinelli A. Corros Sci. 2009;51:642.

7. Trindade LG, Goncalves RS. Corros Sci. 2009;51:1578.

8. Bouyanzer A, Hammouti B, Majidi L. Mater Lett. 2006;60:2840.

9. Ebenso EE, Alemu H, Umoren SA, Obot IB. Int J Electrochem Sci. 2008;3:1325.

10. Oguzie EE. Mater Chem Phys. 2006;99:441.

11. Rajendran S, Shanmugapriya S, Rajalakshmi T, Raj AJJA. Corrosion. 2005;61:685.

12. Chauhan LR, Gunasekaran G, Corros Sci. 2007;49:1143.

13. El-Etre AY, Abdallah M, El-Tantawy ZE. Corros Sci. 2005;47:385.

14. Rajendran S, Agasta M, Devi RB, et al. Zastita Materijala 2009;50:77.

15. Li Y, Zhao P, Liang Q, Hou B. Appl. Surf. Sci. 2005;252:1245.

16. Rajendran S, Devi MK, Regis APP, et al. Zastita Materijala. 2009;50:131.

17. Raja PB, Sethuraman MG. Mater Lett. 2008;62:113.

18. Sangeetha M, Rajendran S, Muthumegala TS, Krishnaveni A. Zastita Materijala. 2011;52:3.

19. Eclipta prostrate paramount for hair loss and alopecia citation of Bible. Healthy Hair Highlights News. 22 July 2011.Retrieved 2011-11-09.

20. Roy RK, Thakur M, Dixit VK. Arch Dermatol Res. 2008;300:357. Retrieved 2012-02-13. 
21. Fontana MG. Corrosion engineering. $3^{\text {rd }}$ Ed. New Delhi:TATA McGrawHill; 2006.

22. Umamathi T, Selvi JA, Kanimozhi SA, et al. Ind J Chem Technol. 2008; 15:560.

23. Kanimozhi SA, Rajendran S. Int J Electrochem Sci. 2009;4:353.

24. Anthony N, Sherine HB. Arab J Sci Eng. 2010;35:41.

25. RajendranS, Agasta M, Devi RB, et al. Zastita Materijala. 2009;50:77.

26. Anuradha K, Vimala R, Narayanaswamy B, et al. Chem Eng Comm. 2008;195:352.

27. Selvarani FR, Santhamadharasi S, Sahayaraj JW, et al. Bull Electrochem. 2004;20:561.

28. Johnsirani V, Rajendran S, Sathiyabama J, et al. Bulg Chem Comm. 2012;44:41.

29. Kavipriya k, Sathiyabama J, Rajendran S, Krishnaveni A, Int J Adv Eng Sci Tech. 2012;2:341.

30. Sangeetha M, Rajendran S, Sathiyabama J, et al. Port Electrochim Acta. 2011;29:429.

31. Manivannan M, RajendranS. Res J Chem Sci. 2011;1:42.

32. Pandiarajan M, Prabhakar P, Rajendran S, Eur Chem Bull. 2012;1:238

33. Kalaivani K, Narayanasamy B, Selvi JA, et al. Port Electrochim Acta. 2009;27:177.

34. Rajendran S, Jeyasundari J, Usha P, et al. Port Electrochim Acta. 2009;27:153.

35. Jayashree A, Rajammal F, Selvarani J, et al. Port Electrochim Acta. 2009;27:23.

36. Selvi JA, Rajendran S, Sri VG, et al. Port Electrochim Acta. 2009;27:1.

37. Shanthy P, Rengan P, Chelvan AT, et al. Ind J. Chem Tech. 2009;16:328.

38. Prakash T, Rao NR, Swamy AHMV. Phytomedicine: Int J Phytotherapy Phytopharmacology. 2008; November 01.

39. Muruganantham S, Anbalagan G, RamamurthyvN. Rom J Biophys. 2009; 19:285.

40. Silverstein RM, Webster FX. Spectrometric identification of organic compounds. 6th Ed. Wiley Student Edition;2007.

41. Sherine B, Nasser AJA, Rajendran S. Int J Eng Sci Tech. 2010;2:341.

42. Singh AK, Quraishi MA. Corros Sci. 2011;53:1288.

43. Wang B, Du M, Zhang J, Gao CJ. Corros Sci. 2011;53:353. 